\title{
Early lactation feed intake and milk yield responses of dairy cows offered grass silages harvested at early maturity stages
}

\author{
Å. T. Randby, ${ }^{* 1}$ M. R. Weisbjerg, $†$ P. Nørgaard,‡ and B. Heringstad ${ }^{*}$ \\ *Department of Animal and Aquacultural Sciences, Norwegian University of Life SSciences, N-1432 Ås, Norway \\ †Department of Animal Health and Bioscience, Faculty of Agricultural Sciences, Århus University, DK-8830 Tjele, Denmark \\ ‡Department of Basic Animal and Veterinary Sciences, Faculty of Life Sciences, Copenhagen University, DK-1165 Copenhagen K, Denmark
}

\begin{abstract}
The main objective was to evaluate the potential of grass silages of very high quality to support a high milk yield with a low or moderate, or even without concentrate supplementation. Production responses to increased levels of concentrate supplementation with 3 primary growth grass silages differing in digestibility were studied using 66 Norwegian Red dairy cows. Roundbale silage was produced from a timothy-dominated sward at very early (H1), early (H2), and normal (H3) stages of crop maturity. Crops were rapidly wilted $(<24 \mathrm{~h})$ and a formic acid-based additive was applied. All silages were restrictedly fermented. Silage digestible organic matter in dry matter (DM) values were 747,708 , and $647 \mathrm{~g} / \mathrm{kg}$ of $\mathrm{DM}$ for $\mathrm{H} 1, \mathrm{H} 2$, and $\mathrm{H} 3$, respectively. Dietary treatments were fed in a $3 \times 3$ factorial arrangement of the 3 silages supplemented with 3 concentrate levels $(4,8$, and $12 \mathrm{~kg} / \mathrm{d})$ and, additionally, $\mathrm{H} 1$ was offered without concentrates and $\mathrm{H} 3$ with $16 \mathrm{~kg} / \mathrm{d}$, giving a total of 11 diets. Cows, blocked according to parity and calving date, were introduced to the experiment before calving and kept in the experiment until wk 16 of lactation. Silage was offered ad libitum in loose housing and concentrate was available in automatic feed stations. Intake of grass silage when fed as the sole feed was $16.9 \mathrm{~kg}$ of DM on average for lactation wk 1 to 16 . When $\mathrm{H} 1$ was supplemented with 4 or $8 \mathrm{~kg}$ of concentrates, silage DM intake did not change, but total DM intake increased to 20.6 and 23.7 $\mathrm{kg} / \mathrm{d}$, respectively. Energy-corrected milk (ECM) yield increased from $23.4 \mathrm{~kg}$ when $\mathrm{H} 1$ was offered without concentrate supplement to 29.1 and $32.8 \mathrm{~kg}$ when supplemented with 4 or $8 \mathrm{~kg}$ concentrate, respectively. None of the other diets equaled the yield obtained by $\mathrm{H} 1$ plus $8 \mathrm{~kg}$ of concentrate. Feed intake and yield of cows offered $\mathrm{H} 3$ plus $4 \mathrm{~kg}$ of concentrates were strongly constrained by high dietary fiber concentration. They consumed $16.5 \mathrm{~g}$ of neutral detergent fiber $/ \mathrm{kg}$ of body
\end{abstract}

Received April 15, 2011.

Accepted September 14, 2011.

${ }^{1}$ Corresponding author: ashild.randby@umb.no weight and spent more time eating silage than cows offered other diets. The highest concentrate level within each silage quality produced similar or lower ECM yield than that with $4 \mathrm{~kg}$ less concentrates. The obtained milk yield responses suggest that provision of 8.0, 8.4 , and $11.5 \mathrm{~kg}$ of concentrates to $\mathrm{H} 1, \mathrm{H} 2$, and $\mathrm{H} 3$, respectively, would maximize ECM yield within each silage type. However, H1 may successfully be used with less concentrates, or even without, if future conditions should limit the amount of concentrates available for ruminant production.

Key words: crop maturity, grass silage, early lactation, milk yield

\section{INTRODUCTION}

On a global basis, grasslands cover approximately two-thirds of agricultural land. The increasing demand for human food, including meat and milk, may favor sustainable grassland-based ruminant systems in the future, so that more arable land may be used for crops for direct human consumption and for concentrate feeds for nonruminant species. Grass silage is a valuable forage because of its relatively lower production cost and high nutritive and feeding value for dairy cows if produced at an early growth stage (Zebeli et al., 2010). Compared with other forages, conserved and grazed grasses are complete feeds, rich in energy, protein, and minerals (Peeters, 2008).

Grasses show a wide variation in nutrient composition depending on, for example, species, soil quality, fertilization, and climate. Forage maturity, however, may be the most important factor because increased lignification of fiber with increasing maturity reduces digestibility, especially of plant stems. Grass or grasslegume swards grazed or harvested at a young stage of maturity may support reasonable milk production even without supplements (Steinshamn and Thuen, 2008). When grasses are conserved as silages, the fermentation quality adds a new source of variation to the feed quality. The fermentation quality depends on the weather during harvesting and on the harvesting technique: mowing, wilting, chopping, compaction, type and dos- 
age of silage additive, air exclusion, storage time, and temperature (Charmley, 2001; Borreani and Tabacco, 2008). Silage digestible organic matter in dry matter (DOMD) and the total concentration of fermentation acids were found to be the most important factors determining silage intake by dairy cows (Huhtanen et al., 2007). Silage DM intake by dairy cows is normally lower than DM intake of the same herbage when fed fresh (Cushnahan and Gordon, 1995). However, in recent years, with well-fermented silage, intake may approach that of fresh herbage (Cushnahan and Mayne, 1995; Charmley, 2001).

Kristensen and Skovborg (1990) examined grass silages harvested at 3 stages of maturity supplemented with $3.5,6.5$, and $9.5 \mathrm{~kg}$ of concentrate DM to dairy cows in $3 \times 3$ factorial continuous design in early lactation. They concluded that it was not possible to obtain the same milk production with low energy silage as with high energy silage by increasing concentrate supplementation, possibly because of reduced fiber digestion and increased partitioning of nutrients toward body stores at higher concentrate intake. In that experiment, silage and concentrates were fed separately twice daily. Using TMR based on high and medium feed value silages to dairy cows, Ferris et al. (2001) detected reduced fiber digestibility with increasing inclusion of concentrates. However, total ration ME concentration remained unaffected (high feed value) or increased (medium feed value) with increasing concentrate inclusion in the diet. Maximum milk yields, that were similar for the 2 silages, were obtained when offered with maximum concentrate allowance, $70 \%$ of diet DM for the high feed value silage and $80 \%$ of diet DM with the medium feed value silage.

The main objective of the present study was to determine to what extent silage from very early or early harvested grass-clover crops could support high milk yield with a low or moderate, or even zero, input of concentrates. Possible silage by concentrate interactions were the main interest.

\section{MATERIALS AND METHODS}

\section{Preparation of Grass Silages}

The primary growths of 5 leys, all sown with the same grass-red clover seed mixture comprising timothy (Phleum pratense) 'Grindstad' (50\%), meadow fescue (Festuca pratensis) 'Fure' (35\%), and red clover (Trifolium pratense) 'Nordi' (15\%) were used for silage preparation. The swards were fertilized on April 26-27, with $69 \mathrm{~kg}$ of $\mathrm{N}, 13 \mathrm{~kg}$ of $\mathrm{P}$, and $33 \mathrm{~kg}$ of $\mathrm{K} / \mathrm{ha}$. A fixed proportion $(50,30$, and $20 \%$, respectively) of each sward was cut at each of 3 maturity stages (harvesting times) in the primary growth: May 30 to June 1 (H1), June 6 to 8 (H2), and June 14 to 16 (H3). The botanical composition for $\mathrm{H} 1, \mathrm{H} 2$, and $\mathrm{H} 3$, respectively, was 68,56 , and $53 \%$ timothy; 21,32 , and $33 \%$ meadow fescue; 5,4 , and $5 \%$ red clover; and 6,8 , and $9 \%$ other species, mainly common couch grass (Elytrigia repens). The maturity of timothy at harvest, given as mean stage by weight (Moore et al., 1991), was measured within $3 \mathrm{~d}$ of harvesting. The mean stage by weight values of $2.44,2.73$, and 3.30 for the 3 harvesting times, respectively (interpolated to the date of harvest), indicated that stage 1 and 2 were dominated by tillers in the stem elongation phase with 2 and 3 visible nodes, respectively, and stage 3 was dominated by tillers with visible heads, but without head stems (early heading). Compared with common Norwegian practice, H1, H2, and $\mathrm{H} 3$ represented harvesting at very early, early, and normal maturity stages for timothy, respectively. Late harvesting was not examined. Yields of harvested herbage in the primary growth were $3.7,5.1$, and $6.2 \mathrm{t}$ of $\mathrm{DM} /$ ha for $\mathrm{H} 1, \mathrm{H} 2$, and $\mathrm{H} 3$, respectively.

The crop was wilted for 2 to $7 \mathrm{~h}$ during daytime or for 14 to $22 \mathrm{~h}$ overnight, aiming to reach a DM content of $300 \mathrm{~g} / \mathrm{kg}$. The weather was mainly sunny with no precipitation during the wilting period, but with some fog and morning dew at the second harvesting time. The crop was baled using 2 Orkel GP 1260 (Orkel AS, Fannrem, Norway) fixed-chamber roundbalers with 20 fixed knives. GrasAAT Lacto $(780 \mathrm{~g} / \mathrm{kg}$ formic acid, 70 $\mathrm{g} / \mathrm{kg} \mathrm{NH}_{3}$ ) silage additive (Addcon Nordic AS, Porsgrunn, Norway) was applied to the crop at 4.4, 4.3, and $4.3 \mathrm{~L} / \mathrm{t}$ during H1, H2, and H3, respectively. The bales were wrapped in 6 layers of white stretch-plastic film, $0.75 \mathrm{~m}$ wide and $0.025 \mathrm{~mm}$ thick (Raniwrap, AS Rani Plast OY, Finland). Silage was chopped to a median particle length of approximately $100 \mathrm{~mm}$ before feeding. Further details on the preparation of the silages and the composition of fresh herbage are given by Randby et al. (2010).

\section{Diets, Animals, and Design of the Experiment}

The study was conducted at the Animal Production Experimental Centre at the University of Life Sciences (Ås, Norway). Dietary treatments in a $3 \times 3$ factorial arrangement consisted of silages harvested at the 3 maturity stages and supplemented with 3 concentrate levels: 4, 8, and $12 \mathrm{~kg} / \mathrm{d}(\mathbf{C 4}, \mathbf{C 8}$, and $\mathbf{C 1 2}$, respectively) on fresh weight basis. These 9 diets were designated $\mathrm{H} 1 \mathrm{C} 4, \mathrm{H} 1 \mathrm{C} 8, \mathrm{H} 1 \mathrm{C} 12, \mathrm{H} 2 \mathrm{C} 4, \mathrm{H} 2 \mathrm{C} 8, \mathrm{H} 2 \mathrm{C} 12$, H3C4, H3C8, and H3C12, respectively. Additionally, $\mathrm{H} 1$ was offered without concentrates $(\mathrm{H} 1 \mathrm{C0})$ and $\mathrm{H} 3$ 
was offered with $16 \mathrm{~kg}$ of concentrate daily (H3C16), so in total 11 diets were studied. Sixteen kilograms of concentrate was considered the highest level that might improve milk yield when offered with $\mathrm{H} 3$, and equal to the highest amount of concentrates commonly used with grass silages harvested at normal or late maturity stages.

Two concentrates, one mixture based mainly on grain ingredients and one with a higher proportion of protein ingredients, were used. The ingredient composition of the grain concentrate was $30.0 \%$ oats, $18.0 \%$ peas, $17.9 \%$ barley, $10.0 \%$ wheat, $10.0 \%$ wheat bran, $6.0 \%$ extracted heat-treated rapeseed meal, $4.5 \%$ molasses, $1.3 \% \mathrm{CaCO}_{3}, 0.5 \% \mathrm{MgO}, 0.8 \% \mathrm{NaCl}$, and $1.0 \%$ of a mineral and vitamin mix. The composition of the protein concentrate was $32.6 \%$ barley, $15.0 \%$ peas, $15.0 \%$ extracted heat-treated rapeseed meal, $15.0 \%$ rapeseed cake, $10.0 \%$ wheat bran, $5.0 \%$ fish meal LT, $4.5 \%$ molasses, $0.8 \% \mathrm{CaCO}_{3}, 0.03 \% \mathrm{MgO}, 1.0 \% \mathrm{NaCl}$, and $1.0 \%$ of a mineral and vitamin mix. The mineral and vitamin mix contained $25.3 \% \mathrm{Ca}, 8.0 \% \mathrm{P}, 0.8 \% \mathrm{Mg}, 6.5 \mathrm{~g} / \mathrm{kg}$ of $\mathrm{Zn}, 2.5 \mathrm{~g} / \mathrm{kg}$ of Fe, $2.0 \mathrm{~g} / \mathrm{kg}$ of $\mathrm{Mn}, 1.5 \mathrm{~g} / \mathrm{kg}$ of $\mathrm{Cu}$, $202 \mathrm{mg} / \mathrm{kg}$ of I, $35.1 \mathrm{mg} / \mathrm{kg}$ of Se, $26.2 \mathrm{mg} / \mathrm{kg}$ of Co, $500,000 \mathrm{IU} / \mathrm{kg}$ of vitamin $\mathrm{A}, 4.5 \mathrm{~g} / \mathrm{kg}$ of vitamin $\mathrm{E}$, and $200,000 \mathrm{IU} / \mathrm{kg}$ of vitamin D. All cows except those not fed concentrates were offered $4 \mathrm{~kg}$ of the protein concentrate. Cows offered 8, 12, and $16 \mathrm{~kg}$ of concentrates received 4,8 , and $12 \mathrm{~kg}$ of grain concentrate, respectively, in addition to the protein concentrate. Grain and protein concentrates were both offered in automatic feed stations.

The experiment had a continuous design, with 6 cows on each diet. Cows were assigned to 6 blocks, where block 1 comprised primiparous cows irrespective of calving date, and blocks 2 to 6 included cows in their second to eighth lactations, with the earliest calving cows placed in block 2 and the latest calving cows in block 6 . One cow (receiving H2, block 6) was offered, in error, $16 \mathrm{~kg}$ instead of $12 \mathrm{~kg}$ of concentrate daily, and was therefore excluded from all analyses.

The experiment started in September 2006, and each cow was introduced to the experiment 2 to 3 wk before expected calving date. Grass silage was fed ad libitum during the entire study, and a mineral mixture (Pluss Multitilskudd Appetitt, Felleskjøpet Fôrutvikling, Trondheim, Norway) containing $11.0 \% \mathrm{Ca}, 7.0 \% \mathrm{P}$, $6.5 \% \mathrm{Mg}$, and $9.0 \% \mathrm{Na}$ was available for ad libitum intake. All cows, except those in $\mathrm{H} 1 \mathrm{C} 0$, were offered 2 $\mathrm{kg}$ daily of the protein concentrate before calving. From d 1 postcalving, the concentrate allowance (the sum of the grain and protein concentrate) was increased by 0.5 $\mathrm{kg}$ daily, so that the full ration was available from DIM $4,12,20$, and 28 , for cows offered $4,8,12$, and $16 \mathrm{~kg}$, respectively.
Four cows, 1 in each of $\mathrm{H} 1 \mathrm{C} 0, \mathrm{H} 2 \mathrm{C} 4, \mathrm{H} 2 \mathrm{C} 8$, and $\mathrm{H} 3 \mathrm{C} 4$, were treated for ketosis. Three cows, 1 in $\mathrm{H} 1 \mathrm{C} 0$ and 2 in $\mathrm{H} 1 \mathrm{C} 4$, were diagnosed to have laminitis without being severely affected. Two cows, 1 in each of $\mathrm{H} 1 \mathrm{C} 0$ and $\mathrm{H} 3 \mathrm{C} 4$, were treated for parturient paresis. Twelve cows, 1 in each of $\mathrm{H} 1 \mathrm{C} 4$ and $\mathrm{H} 1 \mathrm{C} 8,2$ in $\mathrm{H} 1 \mathrm{C} 12$, 1 in each of $\mathrm{H} 2 \mathrm{C} 4, \mathrm{H} 2 \mathrm{C} 8, \mathrm{H} 2 \mathrm{C} 12$, and $\mathrm{H} 3 \mathrm{C} 4$, and 4 in $\mathrm{H} 3 \mathrm{C} 8$, were treated for mastitis. One cow in $\mathrm{H} 1 \mathrm{C} 4$ was slaughtered at 100 DIM due to gastric ulcer. Apart from the cases of ketosis, the observed diseases were not assumed related to treatments.

\section{Housing and Management}

Cows were housed in freestalls with concrete slatted floors and rubber mat beds with sawdust. Grass silage was fed in bins with vertically moving gates where automatic cow identification ensured each cow access to the correct silage. Eating time for silage was monitored electronically as the time each cow kept the gate open, and intake was recorded by weigh cells underneath each feed bin. The number of available beds and feed bins was the same as the number of cows in the experiment at any time. Feed bins containing the same silage were placed next to each other, and cows could visit any bin containing the offered silage. Eating time for concentrates was assumed to be $4 \mathrm{~min} / \mathrm{kg}$ of concentrate DM intake (Nørgaard et al., 2010). Cows had access to water, silage, concentrates, and mineral mix all day. Silage was fed into the feed bins twice daily. Silage residues were removed Monday, Wednesday, and Friday morning. The bin weighing mechanisms were calibrated weekly.

\section{Milking and Milk Analyses}

Cows were milked twice daily, at 0615 to $0900 \mathrm{~h}$ and 1500 to $1715 \mathrm{~h}$. Milk yield was recorded at each milking, and BW of the cows was recorded after each milking by an electronic balance. Milk samples were collected from 6 milkings every week, conserved with Bronopol (2-bromo-2-nitropropane-1,3-diol) and stored at $4^{\circ} \mathrm{C}$. Pooled weekly samples from each cow, based on proportional production, were analyzed for fat, protein, lactose, MUN, and FFA with an infrared spectrophotometer (MilkoScan 6000, Foss Electric, Hillerød, Denmark). Energy-corrected milk yield was calculated from chemical composition (Sjaunja et al., 1991). Weekly individual milk samples from the first 12 wk in milk (WIM) were stored at $-20^{\circ} \mathrm{C}$ and analyzed colorimetrically for acetone concentration using a Technicon Autoanalyzer II (Bran + Luebbe GmbH, Norderstedt, Germany) as described previously by Randby et al. (1999). 


\section{Digestibility Studies, Feed Samples, Analyses, and Estimation of Feed Values and Nutrient Use Efficiency}

Feed sampling and analyses, sheep digestibility trials, and rumen in sacco studies are described by Randby et al. (2010). The contents of $\mathrm{ME}$ and $\mathrm{NE}_{\mathrm{L}}$ in the feed were calculated from feed chemical composition and digestibility values according to Van Es (1978). Metabolizable protein expressed as AA absorbed in the intestine, protein balance in the rumen $(\mathbf{P B V})$, and requirements for $\mathrm{MP}$ [maintenance: $\mathrm{MP}, \mathrm{g} / \mathrm{d}=3.25$ $\times \mathrm{BW}^{0.75}$, lactation: $\mathrm{MP}, \mathrm{g} / \mathrm{d}=40 \times \mathrm{ECM}(\mathrm{kg})+0.2$ $\times \mathrm{ECM}^{2}$ ) and for PBV (minimum $-200 \mathrm{~g}$ of PBV/d) were calculated according to Madsen et al. (1995). Daily energy balance (EB; MJ of $\mathrm{NE}_{\mathrm{L}}$ ) was calculated as feed energy intake minus energy requirement for maintenance $\left(0.335 \times \mathrm{BW}^{0.75} ; \mathrm{NRC}, 2001\right)$ and milk yield $\left(3.036 \times \mathrm{kg}\right.$ of ECM $+0.0050321 \times \mathrm{ECM}^{2} ;$ Ekern, 1991).

Nitrogen $(\mathrm{N})$ use efficiency was calculated as grams of milk N (milk protein/6.38)/grams of total N intake. Feed conversion rate was calculated as kilograms of ECM/kilograms of DM intake.

\section{Statistical Analyses}

Effect of diet on feed intake and milk yield traits were analyzed using the PROC MIXED procedure in SAS (SAS Institute, 2008). The models for milk yield, milk composition, EB, N use efficiency, and feed conversion rate included fixed effects of diet (11 classes), block (6 classes), and WIM (16 classes), and the diet $\times$ WIM interaction. An autoregressive covariance structure using the "random" (cow within diet) and "repeated" (WIM) statements was chosen, with estimation method REML or MIVQUE0 (if iteration stopped because of infinite likelihood). Body weight and BW gain (BWG) data were analyzed using models including only the fixed effects of diet and block. For treatment comparisons, the sum of squares for experimental diets were further divided into single degree of freedom comparisons of linear and quadratic effects of harvesting time and concentrate level $(4,8$, or $12 \mathrm{~kg})$ and their interactions. Because of 1 excluded cow (H2 with $16 \mathrm{~kg}$ instead of $12 \mathrm{~kg}$ of concentrates), SEM values of the $\mathrm{H} 2 \mathrm{C} 12$ diet (presented in Tables 3 to 7 ) shown in the tables must be multiplied by 1.10 . Correlations and regressions were also calculated using SAS. Optimal concentrate intake for maximal ECM yield within each $\mathrm{H}$ was estimated using the PROC RSREG procedure.

Results were considered statistically significant at $P<0.05$, and $P$-values between 0.05 and 0.1 were considered to indicate trends. Values for $P \geq 0.1$ were considered nonsignificant.

\section{RESULTS}

\section{Feed Composition and Quality}

Composition of grass silages and concentrates are presented in Table 1. Concentrations of fiber (NDF, $\mathrm{ADF}$, and acid detergent lignin) increased, whereas concentrations of $\mathrm{N}$-containing substances $\left(\mathrm{CP}, \mathrm{NH}_{3^{-}}\right.$ $\mathrm{N}$, and buffer-soluble $\mathrm{N}$ ) decreased with increased crop maturity at harvest. Protein concentration decreased more than sulfur concentration, so the $\mathrm{N} / \mathrm{S}$ proportion decreased with increased crop maturity. Water-soluble carbohydrates were high and fermentation acids low, indicating that all silages were of restricted fermentation. The rumen soluble plus degradable portion of $\mathrm{N}$, and the degradable NDF, decreased with increasing crop maturity (Table 2). The apparent total-tract digestibilities in sheep of all nutrients were high for H1 and decreased consistently with increased maturity at harvest. Calculated DOMD for H1 was intermediate between the grain and protein concentrates. The estimated content of MP derived from RUP was much higher in concentrates than in silages, particularly in the protein concentrate, whereas MP derived from rumen microbial protein was higher in silages than in concentrates. The PBV content was high in the protein concentrate and close to zero in the grain concentrate. In silages, it decreased with increased maturity at harvest.

\section{Feed Intake}

On average over all 16 WIM, cows offered H1 as the sole feed ingested approximately the same amount of silage DM as cows offered $\mathrm{H} 1$ with $\mathrm{C} 4$ or $\mathrm{C} 8$ (Table 3). When supplementation was increased to $\mathrm{C} 12$, silage DM intake (SDMI) was reduced. Also for H2, SDMI was similar for cows offered $\mathrm{C} 4$ and $\mathrm{C} 8$, but was reduced for cows offered C12. Cows offered H3 had reduced SDMI with increasing concentrate DM intake (CDMI).

Silage DM intake decreased with increasing crop maturity at harvest. Total daily DM intake (TDMI) decreased linearly with increasing maturity at harvest and increased curvilinearly with increased concentrate supplement, indicating diminishing intake response with increased concentrate level. Expressed on a BW basis, greater depressions in SDMI and TDMI from H1 to $\mathrm{H} 2$ than from $\mathrm{H} 2$ to $\mathrm{H} 3$ produced nonlinear responses to crop maturity at harvest. On a BW basis, SDMI decreased and TDMI increased linearly with increased 
Table 1. Chemical composition of grass silages harvested at 3 maturity stages (H1, H2, H3), and of concentrates

\begin{tabular}{|c|c|c|c|c|c|c|c|c|c|c|}
\hline \multirow[b]{3}{*}{ Item } & \multicolumn{6}{|c|}{ Harvesting time for grass silage ${ }^{1}$} & \multicolumn{4}{|c|}{ Concentrates $^{2}$} \\
\hline & \multicolumn{2}{|c|}{ H1 } & \multicolumn{2}{|c|}{$\mathrm{H} 2$} & \multicolumn{2}{|c|}{ H3 } & \multicolumn{2}{|c|}{ Grain } & \multicolumn{2}{|c|}{ Protein } \\
\hline & Mean & $\mathrm{SE}$ & Mean & $\mathrm{SE}$ & Mean & $\mathrm{SE}$ & Mean & $\mathrm{SE}$ & Mean & $\mathrm{SE}$ \\
\hline $\mathrm{DM}, \mathrm{g} / \mathrm{kg}$ & 299 & 11.4 & 271 & 8.1 & 322 & 12.2 & 923 & 5.0 & 926 & 3.4 \\
\hline $\mathrm{pH}$ & 4.43 & 0.04 & 4.18 & 0.02 & 4.31 & 0.02 & & & & \\
\hline $\mathrm{NH}_{3}-\mathrm{N}, \mathrm{g} / \mathrm{kg}$ of $\mathrm{N}$ & 111 & 6.0 & 130 & 9.3 & 140 & 5.7 & & & & \\
\hline $\mathrm{NH}_{3}-\mathrm{N}, \mathrm{g} / \mathrm{kg}$ of $\mathrm{N}^{3}$ & 82 & 4.8 & 94 & 8.6 & 101 & 4.4 & & & & \\
\hline \multirow[t]{2}{*}{$\mathrm{BSN},{ }^{4} \mathrm{~g} / \mathrm{kg}$ of $\mathrm{N}$} & 714 & 23.0 & 692 & 5.7 & 622 & 23.3 & 267 & $\mathrm{NA}^{5}$ & 324 & NA \\
\hline & & & & & \multicolumn{2}{|c|}{$-\mathrm{g} / \mathrm{kg}$ of $\mathrm{DM}-$} & & & & \\
\hline $\mathrm{OM}$ & 927 & 2.1 & 929 & 3.0 & 935 & 1.4 & 926 & 0.9 & 919 & 1.9 \\
\hline $\mathrm{CP}$ & 166 & 5.9 & 145 & 4.1 & 113 & 2.4 & 165 & 2.1 & 240 & 1.8 \\
\hline Starch & & & & & & & 405 & 7.9 & 251 & 2.2 \\
\hline $\mathrm{WSC}^{6}$ & 81.8 & 4.8 & 80.3 & 6.8 & 62.5 & 3.4 & 36.8 & NA & 56.7 & $\mathrm{NA}$ \\
\hline $\mathrm{NDF}^{7}$ & 477 & 7.2 & 533 & 8.5 & 601 & 8.0 & 207 & 1.7 & 190 & 3.8 \\
\hline $\mathrm{ADF}^{8}$ & 284 & 3.3 & 321 & 5.0 & 359 & 3.6 & 98.2 & NA & 102 & NA \\
\hline $\mathrm{ADL}^{9}$ & 46.4 & 2.01 & 51.2 & 1.46 & 64.7 & 1.89 & 26.5 & NA & 30.7 & NA \\
\hline Fat & 38.0 & 1.66 & 29.6 & 0.81 & 25.2 & 0.70 & 44.5 & 1.6 & 77.3 & 3.0 \\
\hline S & 1.77 & NA & 1.75 & NA & 1.46 & NA & 2.65 & $\mathrm{NA}$ & 3.61 & $\mathrm{NA}$ \\
\hline Lactic acid & 62.4 & 5.3 & 74.7 & 4.0 & 41.1 & 2.5 & & & & \\
\hline Formic acid & 11.1 & 0.81 & 17.7 & 0.93 & 11.7 & 0.75 & & & & \\
\hline Acetic acid & 6.3 & 0.58 & 7.2 & 0.65 & 5.2 & 0.59 & & & & \\
\hline Propionic acid & 0.83 & 0.83 & 0.00 & & 0.00 & & & & & \\
\hline Butyric acid & 0.02 & 0.01 & 0.00 & & 0.01 & 0.01 & & & & \\
\hline Ethanol & 8.2 & 0.72 & 17.1 & 0.97 & 10.1 & 0.81 & & & & \\
\hline
\end{tabular}

${ }^{1}$ For silages: DM, pH, WSC, acids, and ethanol: $\mathrm{n}=12$ for H1, and 13 for H2 and H3. For S: $\mathrm{n}=1$, otherwise $\mathrm{n}=5$.

${ }^{2}$ For concentrates: $\mathrm{n}=6$ where $\mathrm{SE}$ is given, otherwise $\mathrm{n}=1$.

${ }^{3}$ Corrected for $\mathrm{NH}_{3}-\mathrm{N}$ applied with silage additive.

${ }^{4} \mathrm{BSN}=$ buffer-soluble $\mathrm{N}$.

${ }^{5} \mathrm{NA}=$ not available.

${ }^{6} \mathrm{WSC}=$ water-soluble carbohydrates.

${ }^{7}$ Analyzed with amylase and sodium sulfite and expressed exclusive of residual ash.

${ }^{8}$ Expressed exclusive of residual ash.

${ }^{9} \mathrm{ADL}=$ acid detergent lignin determined by oxidation of lignin with permanganate.

concentrate level. The lowest SDMI (/ kg of BW) was found for cows in $\mathrm{H} 3 \mathrm{C} 16$ and the highest for cows in $\mathrm{H} 1 \mathrm{C} 0$. The lowest and highest TDMI (/ kg of BW) were found for cows offered H1, supplemented with $\mathrm{C} 0$ and C12, respectively.

The lowest and highest silage NDF intake $(/ \mathrm{kg}$ of BW) was found for cows offered H3, when supplemented with $\mathrm{C} 16$ and $\mathrm{C} 4$, respectively. Within the $\mathrm{C} 4$ to $\mathrm{C} 12$ range, $\mathrm{NDF}$ intake from silage, and in total, was highest for $\mathrm{H} 3$ and lowest for $\mathrm{H} 2$, when assessed on a BW basis. Silage NDF intake (/kg of BW) decreased linearly with increased concentrate level.

All measures of DM and fiber intake increased with increasing stage of lactation until WIM 8 to 16 , where the maximum values were reached at $14.5 \mathrm{~kg}$ of SDMI, $21.5 \mathrm{~kg}$ of TDMI, $36.3 \mathrm{~g}$ of DM/ $\mathrm{kg}$ of BW, and $15.4 \mathrm{~g}$ of NDF $/ \mathrm{kg}$ of BW on average over all diets. For TDMI, however, a significant diet $\times$ WIM interaction appeared, which also tended to be significant for SDMI $(P$ $=0.09)$ : For $\mathrm{H} 1 \mathrm{C} 0$ and $\mathrm{H} 1$ or $\mathrm{H} 2$ supplemented with $\mathrm{C} 4$ or C8, SDMI and TDMI increased considerably with time, whereas a more moderate increase was found for H3C4 and $\mathrm{H} 3 \mathrm{C} 8$ diets. For $\mathrm{C} 12$ diets, SDMI did not increase with time, but was rather constant throughout the 16 WIM, approximately at 14, 13, and $12 \mathrm{~kg}$ for H1, H2, and H3 diets, respectively. For cows receiving H3C16, SDMI declined from 10.7 to $8.5 \mathrm{~kg}$ through WIM 1 to 6 , increasing thereafter to approximately 9 $\mathrm{kg}$ during WIM 8 to 16.

\section{Diet Composition}

The total diet composition for each treatment, calculated from the measured feed intakes, is presented in Table 4. The diet energy concentrations decreased with plant maturity at harvest and increased slightly with the level of concentrate supplement for $\mathrm{H} 1$ and $\mathrm{H} 2$, and clearly for H3. The silage-only diet provided the poorest MP supply. Increasing concentrate level improved diet MP concentration considerably, whereas only a small decrease in diet MP concentration was found with increased maturity at harvest. However, the 
Table 2. Sheep apparent digestibility of nutrients, in sacco degradation, and calculated feed values of grass silages harvested at 3 maturity stages (H1, H2, H3), and of concentrates (partly after Randby et al., 2010)

\begin{tabular}{|c|c|c|c|c|c|c|c|c|c|}
\hline \multirow[b]{2}{*}{ Item } & \multicolumn{3}{|c|}{ Harvesting time for silage } & \multirow[b]{2}{*}{ SEM } & \multicolumn{3}{|c|}{ Contrasts, $P$-value } & \multicolumn{2}{|c|}{ Concentrates } \\
\hline & H1 & $\mathrm{H} 2$ & H3 & & $\mathrm{H} 1-\mathrm{H} 2$ & $\mathrm{H} 2-\mathrm{H} 3$ & H1-H3 & Grain & Protein \\
\hline \multicolumn{10}{|l|}{ Sheep digestibility } \\
\hline $\mathrm{DM}$ & 0.794 & 0.756 & 0.690 & 0.0092 & 0.1 & 0.04 & 0.02 & 0.791 & 0.830 \\
\hline $\mathrm{OM}$ & 0.806 & 0.763 & 0.693 & 0.0087 & 0.07 & 0.03 & 0.01 & 0.779 & 0.822 \\
\hline $\mathrm{CP}$ & 0.781 & 0.755 & 0.682 & 0.0085 & NS & 0.03 & 0.01 & 0.830 & 0.837 \\
\hline NDF & 0.805 & 0.750 & 0.669 & 0.0098 & 0.06 & 0.03 & 0.01 & 0.248 & 0.470 \\
\hline $\mathrm{DOMD}^{1}$ & 0.747 & 0.708 & 0.647 & 0.0081 & 0.08 & 0.03 & 0.01 & 0.725 & 0.761 \\
\hline \multicolumn{10}{|c|}{ In sacco degradation of total $\mathrm{N}$} \\
\hline Soluble N & 0.732 & 0.755 & 0.662 & 0.0041 & 0.02 & $<0.001$ & $<0.001$ & 0.252 & 0.368 \\
\hline Degradable N & 0.217 & 0.159 & 0.171 & 0.0042 & $<0.001$ & NS & 0.002 & 0.709 & 0.580 \\
\hline $\mathrm{N} \mathrm{k}_{\mathrm{d}}, 2 / \mathrm{h}$ & 0.072 & 0.043 & 0.059 & 0.0033 & 0.004 & 0.03 & 0.06 & 0.074 & 0.059 \\
\hline $\mathrm{EPD}_{8}{ }^{3}$ & 0.835 & 0.810 & 0.734 & 0.0026 & 0.003 & $<0.001$ & $<0.001$ & 0.591 & 0.612 \\
\hline Digestibility of RUP 4 & 0.810 & 0.797 & 0.764 & 0.0002 & $<0.001$ & $<0.001$ & $<0.001$ & 0.923 & 0.864 \\
\hline Indigestible $\mathrm{N}^{5}$ & 0.031 & 0.038 & 0.063 & 0.0002 & 0.002 & $<0.001$ & $<0.001$ & 0.032 & 0.053 \\
\hline \multicolumn{10}{|c|}{ In sacco degradation of total NDF } \\
\hline Degradable NDF & 0.906 & 0.872 & 0.791 & 0.0023 & 0.009 & 0.002 & $<0.001$ & 0.711 & 0.645 \\
\hline $\mathrm{NDF} \mathrm{k}_{\mathrm{d}},{ }^{6} / \mathrm{h}$ & 0.058 & 0.047 & 0.046 & 0.0029 & 0.06 & NS & 0.04 & & \\
\hline $\mathrm{iNDF}^{7}$ & 0.094 & 0.128 & 0.209 & 0.0023 & 0.009 & 0.002 & $<0.001$ & 0.289 & 0.355 \\
\hline $\mathrm{ENDFD}_{3}^{8}$ & 0.582 & 0.513 & 0.450 & 0.0075 & 0.003 & 0.004 & $<0.001$ & & \\
\hline \multicolumn{10}{|c|}{ Energy and protein values } \\
\hline $\mathrm{ME}, \mathrm{MJ} / \mathrm{kg}$ of DM & 11.36 & 10.67 & 9.62 & 0.123 & 0.06 & 0.03 & 0.01 & 11.58 & 13.0 \\
\hline $\mathrm{NE}_{\mathrm{L}}, \mathrm{MJ} / \mathrm{kg}$ of $\mathrm{DM}$ & 6.75 & 6.26 & 5.52 & 0.086 & 0.06 & 0.03 & 0.01 & 6.96 & 7.96 \\
\hline $\mathrm{MP}_{\mathrm{RUP}},{ }^{9} \mathrm{~g} / \mathrm{kg}$ of DM & 14.2 & 13.6 & 14.1 & $\mathrm{NA}^{10}$ & NA & NA & NA & 53.1 & 66.2 \\
\hline $\mathrm{MP}_{\mathrm{RMP}},{ }^{11} \mathrm{~g} / \mathrm{kg}$ of DM & 63.1 & 61.8 & 59.3 & 0.69 & NS & NS & 0.06 & 58.5 & 52.3 \\
\hline $\mathrm{MP}, \mathrm{g} / \mathrm{kg}$ of DM & 77.2 & 75.4 & 73.3 & 0.69 & NS & NS & 0.06 & 111.6 & 118.5 \\
\hline $\mathrm{PBV}^{12} \mathrm{~g} / \mathrm{kg}$ of DM & 29.6 & 8.2 & -21.6 & 1.17 & 0.006 & 0.003 & 0.001 & -0.9 & 54.2 \\
\hline
\end{tabular}

${ }^{1}$ Digestible OM in DM.

${ }^{2}$ Fractional degradation rate of degradable N, per h.

${ }^{3}$ Effective rumen protein degradability, calculated with rumen passage rate of 0.08 per $\mathrm{h}$.

${ }^{4}$ Intestinal digestibility of RUP.

${ }^{5}$ Rumen and intestinal indigestible N.

${ }^{6}$ Fractional degradation rate of degradable NDF, per $\mathrm{h}$.

${ }^{7}$ Indigestible NDF after $288 \mathrm{~h}$ of rumen incubation.

${ }^{8}$ Effective rumen NDF degradability, calculated with rumen passage rate of 0.03 per $\mathrm{h}$.

${ }^{9} \mathrm{MP}$ derived from RUP.

${ }^{10} \mathrm{NA}=$ not available.

${ }^{11} \mathrm{MP}$ derived from rumen microbial protein.

${ }^{12}$ Protein balance in the rumen.

concentration of PBV was strongly affected by plant maturity at harvest.

\section{Eating Time}

The time each cow kept the gate of the silage feed bin open, here used as a measure of eating time, is presented in Table 5. The time spent eating silage increased linearly with plant maturity at harvest and decreased linearly with increasing concentrate allowance. Eating time per kilogram of silage DM and NDF intake increased linearly with plant maturity at harvest, but was not affected by concentrate allowance. The total time spent eating, assuming $4 \mathrm{~min} / \mathrm{kg}$ of CDMI, increased linearly with plant maturity at harvest and decreased linearly with increasing concentrate allowance within the $\mathrm{C} 4$ to $\mathrm{C} 12$ range. Cows offered silage only, however, spent the shortest time eating. Eating time per kilogram of total DM and NDF intake increased linearly with plant maturity and decreased linearly with concentrate allowance.

The time spent eating silage and the total time spent eating increased with increasing WIM. The time spent eating per kilogram of SDMI also increased slightly with time, from 14 to $15.5 \mathrm{~min} / \mathrm{kg}$ of SDMI during WIM 1 to 16, but for TDMI no overall effect of WIM was seen. However, eating time per kilogram of TDMI differed among diets. For diet $\mathrm{H} 2 \mathrm{C} 4$ and $\mathrm{H} 3 \mathrm{C} 4$, eating time per kilogram of TDMI increased from approximately 12 to $14 \mathrm{~min}$, and from 14 to $16 \mathrm{~min}$, respectively, in the course of the 16 wk. For diet $\mathrm{H} 3 \mathrm{C} 16$, the full concentrate allowance was not consumed until WIM 6 , and during the first $5 \mathrm{wk}$, eating time per kilogram of TDMI was reduced from approximately 16 to $10.5 \mathrm{~min}$, after 
Table 3. Effect of harvesting time for grass silage (H1, H2, H3) and level of concentrate supplement on daily DM and fiber (NDF) intake of cows (mean values for lactation wk 1-16)

\begin{tabular}{|c|c|c|c|c|c|c|c|c|c|}
\hline \multirow{3}{*}{$\begin{array}{l}\text { Silage harvest } \\
\text { time }\end{array}$} & \multirow{3}{*}{$\begin{array}{l}\text { Concentrate } \\
\text { level, } \mathrm{kg}^{1}\end{array}$} & \multicolumn{4}{|c|}{$\mathrm{DM}, \mathrm{kg}$} & \multirow{2}{*}{\multicolumn{2}{|c|}{$\mathrm{DM}, \mathrm{g} / \mathrm{kg}$ of $\mathrm{BW}$}} & \multirow{2}{*}{\multicolumn{2}{|c|}{$\mathrm{NDF}, \mathrm{g} / \mathrm{kg}$ of $\mathrm{BW}$}} \\
\hline & & \multicolumn{2}{|c|}{ Concentrates } & \multirow[b]{2}{*}{ Silage } & \multirow[b]{2}{*}{ Total diet } & & & & \\
\hline & & Protein & Grain & & & Silage & Total diet & Silage & Total diet \\
\hline \multirow[t]{4}{*}{ H1 } & 0 & 0 & 0 & 16.9 & 16.9 & 30.1 & 30.1 & 14.3 & 14.3 \\
\hline & 4 & 3.62 & 0 & 17.0 & 20.6 & 29.7 & 36.1 & 14.2 & 15.4 \\
\hline & 8 & 3.61 & 3.42 & 16.7 & 23.7 & 27.6 & 39.3 & 13.2 & 15.5 \\
\hline & 12 & 3.31 & 6.14 & 14.2 & 23.6 & 24.4 & 40.8 & 11.7 & 14.9 \\
\hline \multirow[t]{3}{*}{$\mathrm{H} 2$} & 4 & 3.65 & 0 & 14.5 & 18.2 & 24.9 & 31.3 & 13.3 & 14.5 \\
\hline & 8 & 3.61 & 3.13 & 14.4 & 21.1 & 23.9 & 35.2 & 12.7 & 15.0 \\
\hline & 12 & 3.52 & 6.37 & 12.9 & 22.8 & 20.5 & 36.2 & 10.9 & 14.1 \\
\hline \multirow[t]{4}{*}{ H3 } & 4 & 3.65 & 0 & 14.4 & 18.0 & 25.4 & 31.9 & 15.2 & 16.5 \\
\hline & 8 & 3.62 & 3.37 & 13.3 & 20.3 & 21.3 & 32.5 & 12.8 & 15.0 \\
\hline & 12 & 3.54 & 6.31 & 11.9 & 21.7 & 20.0 & 36.7 & 12.0 & 15.4 \\
\hline & 16 & 3.30 & 8.74 & 9.3 & 21.4 & 16.6 & 38.1 & 10.0 & 14.3 \\
\hline $\mathrm{SEM}^{2}$ & & & & 0.49 & 0.55 & 0.91 & 1.10 & 0.48 & 0.52 \\
\hline$P$-value & $\operatorname{Diet}^{3}$ & & & $<0.001$ & $<0.001$ & $<0.001$ & $<0.001$ & $<0.001$ & NS \\
\hline \multirow[t]{6}{*}{$P$-value } & Contrasts ${ }^{4}$ & & & & & & & & \\
\hline & LH & & & $<0.001$ & $<0.001$ & $<0.001$ & $<0.001$ & NS & NS \\
\hline & $\mathrm{QH}$ & & & 0.09 & NS & 0.02 & 0.01 & 0.02 & 0.02 \\
\hline & LC & & & $<0.001$ & $<0.001$ & $<0.001$ & $<0.001$ & $<0.001$ & NS \\
\hline & $\mathrm{QC}$ & & & 0.08 & 0.03 & NS & NS & NS & NS \\
\hline & $\mathrm{H} \times \mathrm{C}$ & & & NS & NS & NS & NS & NS & NS \\
\hline \multirow[t]{2}{*}{$P$-value } & WIM $^{5}$ & & & $<0.001$ & $<0.001$ & $<0.001$ & $<0.001$ & $<0.001$ & $<0.001$ \\
\hline & Diet $\times$ WIM & & & 0.09 & 0.03 & 0.08 & NS & NS & NS \\
\hline
\end{tabular}

${ }^{1}$ Where $4 \mathrm{~kg}$ is protein concentrate only; 8,12 , and $16 \mathrm{~kg}=4 \mathrm{~kg}$ of protein concentrate plus grain concentrate to total level.

${ }^{2}$ For the diet with 1 missing value (H2, $12 \mathrm{~kg}$ of concentrate), SEM was multiplied by 1.10.

${ }^{3}$ All 11 diets.

${ }^{4}$ Contrasts including only the 9 diets with 4,8 , or $12 \mathrm{~kg}$ concentrates. $\mathrm{LH}$ and $\mathrm{QH}=$ linear and quadratic effects of harvesting time, $\mathrm{LC}$ and $\mathrm{QC}$ $=$ linear and quadratic effects of concentrate level, $\mathrm{H} \times \mathrm{C}=$ harvesting time $\times$ concentrate level interaction.

${ }^{5} \mathrm{WIM}=$ week in milk.

which it remained stable. For other diets, eating time per kilogram of TDMI was rather stable throughout the 16 wk. Eating time per kilogram of silage NDF and total NDF increased with increasing WIM.

\section{Milk Production and Composition}

Milk yield decreased linearly with increasing plant maturity at harvest and increased linearly with increasing concentrate allowance (Table 6). However, within $\mathrm{H} 1$, when $\mathrm{C} 0$ was included, milk yield tended to be quadratically related to concentrate level $(P=0.06$, contrast not presented), with a negative response to the highest level. For H2, milk yield was similar for $\mathrm{C} 8$ and $\mathrm{C} 12$, and for $\mathrm{H} 3$, no milk yield response to the highest concentrate level was found. Similar yield responses were also found for ECM, fat, protein, and lactose. Based on quadratic regression, the concentrate intake for maximum ECM yield was at 7.4, 7.7, and $10.6 \mathrm{~kg}$ of DM, equivalent to $8.0,8.4$, and $11.5 \mathrm{~kg}$ of concentrate on an as-fed basis.

Milk fat concentration tended to decrease curvilinearly with increasing maturity at harvest, with lower concentrations for $\mathrm{H} 3$ than for $\mathrm{H} 2$ and $\mathrm{H} 1(P=0.01$, contrast not presented). Milk urea concentrations decreased linearly with increasing plant maturity at harvest. Milk FFA concentrations increased linearly with increasing plant maturity at harvest and decreased with increasing concentrate level.

All yield and milk concentration measurements were affected by WIM, and diet $\times$ WIM interactions were found for all yield measurements and for milk fat concentration. On average, over all diets, daily milk yield peaked at $30.4 \mathrm{~kg}$ in WIM 5, and decreased thereafter by $0.28 \mathrm{~kg} /$ wk. Cows on the H1C 8 diet produced the highest total milk yield, and their maximum yield, 34.9 $\mathrm{kg}$, was also found in WIM 5, with a subsequent weekly decrease of $0.24 \mathrm{~kg}$. Daily milk yield of cows offered silage only (H1C0) was highest in WIM $2(25.4 \mathrm{~kg})$ and decreased thereafter by $0.34 \mathrm{~kg} / \mathrm{wk}$, whereas cows offered H3C16 increased milk yield slowly after calving and reached maximum yield $(31.3 \mathrm{~kg})$ in WIM 8 , with a weekly decrease thereafter of only $0.18 \mathrm{~kg}$.

On average, over all diets, daily milk fat concentration decreased from $45.8 \mathrm{~g} / \mathrm{kg}$ in WIM 1 to a stable minimum value of $39.4 \mathrm{~g} / \mathrm{kg}$ during WIM 5 to 13 , after which a slight increase to $40.3 \mathrm{~g} / \mathrm{kg}$ in WIM 16 was observed. This increase during the last weeks of the 
Table 4. Effect of harvesting time for grass silage (H1, H2, H3) and level of concentrate supplement on diet composition (mean values for lactation wk 1-16)

\begin{tabular}{|c|c|c|c|c|c|c|c|c|c|c|c|}
\hline \multirow[b]{2}{*}{$\begin{array}{l}\text { Silage harvest } \\
\text { time }\end{array}$} & \multirow[b]{2}{*}{$\begin{array}{l}\text { Concentrate } \\
\text { level, } \mathrm{kg}^{1}\end{array}$} & \multicolumn{6}{|c|}{$\mathrm{g} / \mathrm{kg}$ of $\mathrm{DM}$} & \multicolumn{2}{|c|}{$\mathrm{MJ} / \mathrm{kg}$ of $\mathrm{DM}$} & \multicolumn{2}{|c|}{$\mathrm{g} / \mathrm{kg}$ of $\mathrm{DM}$} \\
\hline & & $\mathrm{OM}$ & $\mathrm{CP}$ & Fat & $\mathrm{NDF}$ & $\begin{array}{l}\mathrm{ST}+ \\
\mathrm{WSC}^{2}\end{array}$ & $\begin{array}{l}\text { Acids }+ \\
\text { ethanol }\end{array}$ & ME & $\mathrm{NE}_{\mathrm{L}}$ & MP & $\mathrm{PBV}^{3}$ \\
\hline \multirow[t]{4}{*}{ H1 } & 0 & 927 & 161 & 38 & 477 & 82 & 89 & 11.4 & 6.75 & 77.2 & 29.6 \\
\hline & 4 & 926 & 175 & 46 & 426 & 120 & 73 & 11.7 & 6.97 & 84.6 & 34.0 \\
\hline & 8 & 926 & 174 & 45 & 394 & 167 & 62 & 11.6 & 6.97 & 88.5 & 29.0 \\
\hline & 12 & 926 & 173 & 45 & 367 & 205 & 53 & 11.7 & 6.97 & 91.9 & 25.2 \\
\hline \multirow{3}{*}{$\mathrm{H} 2$} & 4 & 927 & 160 & 40 & 462 & 124 & 93 & 11.2 & 6.61 & 84.3 & 17.7 \\
\hline & 8 & 927 & 160 & 40 & 425 & 171 & 79 & 11.2 & 6.66 & 88.2 & 14.8 \\
\hline & 12 & 927 & 162 & 40 & 390 & 213 & 67 & 11.3 & 6.72 & 92.0 & 12.8 \\
\hline \multirow[t]{4}{*}{ H3 } & 4 & 932 & 135 & 36 & 516 & 110 & 54 & 10.3 & 6.02 & 82.6 & -6.0 \\
\hline & 8 & 931 & 141 & 38 & 462 & 167 & 45 & 10.6 & 6.19 & 87.7 & -4.6 \\
\hline & 12 & 930 & 146 & 39 & 421 & 210 & 37 & 10.7 & 6.33 & 91.7 & -3.3 \\
\hline & 16 & 929 & 151 & 40 & 380 & 250 & 30 & 10.9 & 6.47 & 95.6 & -1.6 \\
\hline $\mathrm{SEM}^{4}$ & & 0.074 & 0.58 & 0.25 & 2.33 & 1.96 & 0.57 & 0.015 & 0.011 & 0.26 & 0.30 \\
\hline$P$-value & $\operatorname{Diet}^{5}$ & $<0.001$ & $<0.001$ & $<0.001$ & $<0.001$ & $<0.001$ & $<0.001$ & $<0.001$ & $<0.001$ & $<0.001$ & $<0.001$ \\
\hline \multirow[t]{6}{*}{$P$-value } & Contrasts $^{6}$ & & & & & & & & & & \\
\hline & $\mathrm{LH}$ & $<0.001$ & $<0.001$ & $<0.001$ & $<0.001$ & NS & $<0.001$ & $<0.001$ & $<0.001$ & $<0.001$ & $<0.001$ \\
\hline & $\mathrm{QH}$ & $<0.001$ & $<0.001$ & $<0.001$ & 0.005 & $<0.001$ & $<0.001$ & $<0.001$ & $<0.001$ & 0.06 & $<0.001$ \\
\hline & $\mathrm{LC}$ & $<0.001$ & $<0.001$ & 0.006 & $<0.001$ & $<0.001$ & $<0.001$ & $<0.001$ & $<0.001$ & $<0.001$ & $<0.001$ \\
\hline & $\mathrm{QC}$ & NS & NS & NS & 0.07 & 0.003 & 0.08 & NS & NS & NS & NS \\
\hline & $\mathrm{H} \times \mathrm{C}$ & $<0.001$ & $<0.001$ & $<0.001$ & $<0.001$ & $<0.001$ & 0.02 & $<0.001$ & $<0.001$ & 0.001 & $<0.001$ \\
\hline \multirow[t]{2}{*}{$P$-value } & WIM $^{7}$ & $<0.001$ & $<0.001$ & $<0.001$ & $<0.001$ & $<0.001$ & $<0.001$ & $<0.001$ & $<0.001$ & $<0.001$ & NS \\
\hline & Diet $\times$ WIM & $<0.001$ & $<0.001$ & $<0.001$ & $<0.001$ & $<0.001$ & $<0.001$ & $<0.001$ & $<0.001$ & $<0.001$ & $<0.001$ \\
\hline
\end{tabular}

${ }^{1}$ Where $4 \mathrm{~kg}$ is protein concentrate only; 8,12 , and $16 \mathrm{~kg}=4 \mathrm{~kg}$ of protein concentrate plus grain concentrate to total level.

${ }^{2} \mathrm{ST}+\mathrm{WSC}=$ starch + water-soluble carbohydrates.

${ }^{3} \mathrm{PBV}=$ protein balance in the rumen.

${ }^{4}$ For the diet with 1 missing value (H2, $12 \mathrm{~kg}$ of concentrate), SEM was multiplied by 1.10 .

${ }^{5}$ All 11 diets.

${ }^{6}$ Contrasts including only the 9 diets with 4,8 , or $12 \mathrm{~kg}$ of concentrates. $\mathrm{LH}$ and $\mathrm{QH}=$ linear and quadratic effects of harvesting time, LC and $\mathrm{QC}=$ linear and quadratic effects of concentrate level, $\mathrm{H} \times \mathrm{C}=$ harvesting time $\times$ concentrate level interaction.

${ }^{7} \mathrm{WIM}=$ week in milk.

experiment was, however, due to increases in milk fat concentrations for cows on the $\mathrm{H} 1 \mathrm{C} 0, \mathrm{H} 1 \mathrm{C} 4$, and $\mathrm{H} 2 \mathrm{C} 4$ diets only, the same diets that also gave the highest mean milk fat concentrations, whereas fat concentrations remained close to the minimum values toward the end of experiment for the other diets. On average, over all diets, milk protein concentration decreased sharply from $38.4 \mathrm{~g} / \mathrm{kg}$ in WIM 1 to the minimum value of 31.2 $\mathrm{g} / \mathrm{kg}$ in WIM 6 and 7, and increased thereafter to 32.7 $\mathrm{g} / \mathrm{kg}$ in WIM 15 and 16. The lactose concentration was more stable than that of other milk constituents, and on average, over all diets, it increased from $44.3 \mathrm{~g} / \mathrm{kg}$ in WIM 1 to $45.7 \mathrm{~g} / \mathrm{kg}$ in WIM 5, before it decreased slightly to $45.2 \mathrm{~g} / \mathrm{kg}$ in WIM 16 .

The yields of ECM, milk fat, and lactose followed similar patterns for the various diets as did milk yield. However, compared with milk yield, ECM and milk fat yields of diets $\mathrm{H} 1 \mathrm{C} 0, \mathrm{H} 1 \mathrm{C} 4$, and $\mathrm{H} 2 \mathrm{C} 4$ were slightly more persistent toward the end of experiment because of the increases in milk fat concentration. On average for cows on all diets, MUN increased during the entire period. The average milk FFA concentration was 0.52 $\mathrm{mEq} / \mathrm{L}$ in WIM 1 , followed by a stable low value at approximately $0.38 \mathrm{mEq} / \mathrm{L}$ in WIM 2 to 7 and then an increase to $0.60 \mathrm{mEq} / \mathrm{L}$ in WIM 16.

\section{BW, EB, and Milk Acetone Concentration}

Some dietary treatments included cows with an initial higher BW than other treatments, but differences in BW at the onset of lactation were not significant (Table 7). Final BW was higher for cows offered C12 compared with $\mathrm{C} 4$, in spite of similar initial $\mathrm{BW}$ of cows in these treatments within crop maturity stages. Body weight gains increased linearly within the C4 to C12 range and decreased linearly with increasing stage of crop maturity. The increase due to concentrate level was caused by differences occurring during the first 5 wk, when cows offered $\mathrm{C} 4$ with $\mathrm{H} 1, \mathrm{H} 2$, and $\mathrm{H} 3$ lost 140, 769 , and $732 \mathrm{~g} / \mathrm{d}$, respectively, whereas cows offered C12 showed increased BW (184 and $153 \mathrm{~g} / \mathrm{d}$ for H1 and $\mathrm{H} 2$, respectively) or stable $\mathrm{BW}(-36 \mathrm{~g} / \mathrm{d}$ for $\mathrm{H} 3$; data not presented). In contrast, the decrease in $\mathrm{BW}$ due to increased crop maturity stage was mainly due to differences occurring from WIM 6 to 11, when cows within the $\mathrm{C} 4$ to $\mathrm{C} 12$ range offered $\mathrm{H} 1, \mathrm{H} 2$, and $\mathrm{H} 3$ had 
Table 5. Effect of harvesting time for grass silage (H1, H2, H3) and level of concentrate supplement on daily eating time (mean values for lactation wk 1-16)

\begin{tabular}{|c|c|c|c|c|c|c|c|}
\hline \multirow[b]{2}{*}{$\begin{array}{l}\text { Silage harvest } \\
\text { time }\end{array}$} & \multirow[b]{2}{*}{$\begin{array}{l}\text { Concentrate } \\
\text { level, } \mathrm{kg}^{1}\end{array}$} & \multicolumn{3}{|c|}{ Eating time for silage } & \multicolumn{3}{|c|}{ Total ration eating time ${ }^{2}$} \\
\hline & & $\min$ & $\begin{array}{l}\min / \mathrm{kg} \\
\text { of DM }\end{array}$ & $\begin{array}{l}\min / \mathrm{kg} \\
\text { of } \mathrm{NDF}\end{array}$ & $\min$ & $\begin{array}{l}\min / \mathrm{kg} \\
\text { of } \mathrm{DM}\end{array}$ & $\begin{array}{l}\min / \mathrm{kg} \\
\text { of NDF }\end{array}$ \\
\hline \multirow[t]{4}{*}{ H1 } & 0 & 186 & 11.0 & 23.1 & 186 & 11.0 & 23.1 \\
\hline & 4 & 203 & 12.3 & 25.8 & 218 & 10.8 & 25.3 \\
\hline & 8 & 209 & 12.6 & 26.5 & 237 & 10.0 & 25.5 \\
\hline & 12 & 163 & 11.7 & 24.5 & 201 & 8.6 & 23.4 \\
\hline \multirow[t]{3}{*}{$\mathrm{H} 2$} & 4 & 221 & 15.7 & 29.4 & 235 & 13.2 & 28.6 \\
\hline & 8 & 206 & 14.5 & 27.2 & 233 & 11.1 & 26.1 \\
\hline & 12 & 170 & 13.2 & 24.9 & 210 & 9.2 & 23.7 \\
\hline \multirow[t]{4}{*}{ H3 } & 4 & 257 & 18.1 & 30.1 & 271 & 15.2 & 29.4 \\
\hline & 8 & 235 & 17.8 & 29.6 & 263 & 13.0 & 28.2 \\
\hline & 12 & 212 & 17.9 & 29.9 & 251 & 11.6 & 27.7 \\
\hline & 16 & 192 & 21.3 & 35.4 & 240 & 11.6 & 30.5 \\
\hline $\mathrm{SEM}^{3}$ & & 11.0 & 0.99 & 1.83 & 11.6 & 0.64 & 1.52 \\
\hline$P$-value & Diet $^{4}$ & $<0.001$ & $<0.001$ & 0.001 & $<0.001$ & $<0.001$ & 0.01 \\
\hline \multirow{6}{*}{$P$-value } & Contrasts $^{5}$ & & & & & & \\
\hline & LH & $<0.001$ & $<0.001$ & 0.007 & $<0.001$ & $<0.001$ & 0.005 \\
\hline & $\mathrm{QH}$ & 0.08 & NS & NS & 0.1 & NS & NS \\
\hline & $\mathrm{LC}$ & $<0.001$ & NS & NS & 0.03 & $<0.001$ & 0.03 \\
\hline & $\mathrm{QC}$ & NS & NS & NS & NS & NS & NS \\
\hline & $\mathrm{H} \times \mathrm{C}$ & NS & NS & NS & NS & NS & NS \\
\hline \multirow[t]{2}{*}{$P$-value } & $\mathrm{WIM}^{6}$ & $<0.001$ & $<0.001$ & $<0.001$ & $<0.001$ & NS & 0.01 \\
\hline & Diet $\times$ WIM & NS & NS & NS & NS & $<0.001$ & NS \\
\hline
\end{tabular}

${ }^{1}$ Where $4 \mathrm{~kg}$ is protein concentrate only; 8,12 , and $16 \mathrm{~kg}=4 \mathrm{~kg}$ of protein concentrate plus grain concentrate to total level.

${ }^{2}$ Calculated assuming 4 min eating time per $\mathrm{kg}$ of concentrate DM.

${ }^{3}$ For the diet with 1 missing value (H2, $12 \mathrm{~kg}$ of concentrate), SEM was multiplied by 1.10 .

${ }^{4}$ All 11 diets.

${ }^{5}$ Contrasts including only the 9 diets with 4,8 , or $12 \mathrm{~kg}$ of concentrates. $\mathrm{LH}$ and $\mathrm{QH}=$ linear and quadratic effects of harvesting time, $\mathrm{LC}$ and $\mathrm{QC}=$ linear and quadratic effects of concentrate level, $\mathrm{H} \times \mathrm{C}=$ harvesting time $\times$ concentrate level interaction.

${ }^{6} \mathrm{WIM}=$ week in milk.

BW changes of $+326,+313$, and $-66 \mathrm{~g} / \mathrm{d}$, respectively (data not presented). At the start of lactation, cows offered $\mathrm{H} 1 \mathrm{C} 0, \mathrm{H} 2 \mathrm{C} 4$, and $\mathrm{H} 3 \mathrm{C} 4$ lost approximately 30 $\mathrm{kg}$ before their BW started to increase, and only cows fed these 3 diets lost weight, on average, for the entire period (Table 7).

Calculated daily EB decreased linearly with increased crop maturity and increased linearly with increased concentrate level (Table 7). On average, over all diets, EB increased during the entire period, from $-20 \mathrm{MJ}$ of $\mathrm{NE}_{\mathrm{L}}$ in WIM 1 to $17 \mathrm{MJ}$ of $\mathrm{NE}_{\mathrm{L}}$ in WIM 16, with zero EB in WIM 3 to 4, and with a diminishing weekly increase with time.

Milk acetone concentrations peaked at 1.7, 1.7, 2.0, and $2.8 \mathrm{mM}$ for the 4 cows diagnosed with and treated for clinical ketosis. Apart from those cows, the total mean acetone concentration was $0.09 \mathrm{mM}$ and the maximum individual concentration $0.66 \mathrm{mM}$. Acetone concentrations decreased linearly with increased concentrate level, but were not affected by crop maturity stage (Table 7). However, milk acetone concentrations were influenced by the block of cows $(P=0.02)$, and cows calving late in the season had the highest average values. On average, over all diets, acetone concentra- tion was $0.08 \mathrm{mM}$ in WIM 1 and increased to $0.20 \mathrm{mM}$ in WIM 6 (the time when the 4 cows got ketosis), after which it fell to a constant level of approximately 0.11 $\mathrm{m} M$ in WIM 7 to 12 .

\section{Nitrogen Use Efficiency and Feed Conversion Rate}

Nitrogen use efficiency for milk production increased with increasing stage of crop maturity and tended to decrease with increasing concentrate level (Table 7). In WIM 1, the average $\mathrm{N}$ use efficiency was 0.38 . It decreased sharply to 0.30 in WIM 3 , and fell slowly thereafter to 0.26 in WIM 16. Feed conversion rate tended to decrease with increasing concentrate level. It also decreased with increasing stage of lactation, from 1.71 in WIM 1 to 1.25 in WIM 16.

\section{DISCUSSION}

\section{Feed Intake}

Silage DMI was high compared with other studies (Rinne et al., 1999a; Dewhurst et al., 2003; McNamee et al., 2005). On a BW basis, maximum TDMI (H1C12) 
Table 6. Effect of harvesting time for grass silage (H1, H2, H3) and level of concentrate supplement on daily milk yield and composition (mean values for lactation wh $1-16$ )

\begin{tabular}{|c|c|c|c|c|c|c|c|c|c|c|c|}
\hline \multirow[b]{2}{*}{$\begin{array}{l}\text { Silage harvest } \\
\text { time }\end{array}$} & \multirow[b]{2}{*}{$\begin{array}{l}\text { Concentrate } \\
\text { level, } \mathrm{kg}^{1}\end{array}$} & \multicolumn{5}{|c|}{ Milk yield } & \multicolumn{5}{|c|}{ Milk composition } \\
\hline & & $\begin{array}{l}\text { Milk, } \\
\text { kg }\end{array}$ & $\begin{array}{l}\text { ECM, } \\
\text { kg }\end{array}$ & $\begin{array}{l}\text { Fat, } \\
\mathrm{g}\end{array}$ & $\begin{array}{l}\text { Protein, } \\
\text { g }\end{array}$ & $\begin{array}{l}\text { Lactose, } \\
\mathrm{g}\end{array}$ & $\begin{array}{l}\text { Fat, } \mathrm{g} \\
\text { / kg }\end{array}$ & $\begin{array}{l}\text { Protein, } \\
\text { g/kg }\end{array}$ & $\begin{array}{l}\text { Lactose, } \\
\mathrm{g} / \mathrm{kg}\end{array}$ & $\begin{array}{l}\text { MUN, } \\
\mathrm{mg} / \mathrm{dL}\end{array}$ & $\begin{array}{l}\text { FFA, } \\
\mathrm{mEq} / \mathrm{L}\end{array}$ \\
\hline \multirow[t]{4}{*}{ H1 } & 0 & 23.7 & 23.4 & 975 & 742 & 1,049 & 41.4 & 31.5 & 44.4 & 11.5 & 0.63 \\
\hline & 4 & 29.1 & 29.1 & 1,200 & 930 & 1,315 & 41.3 & 32.2 & 45.2 & 13.5 & 0.39 \\
\hline & 8 & 32.8 & 32.8 & 1,337 & 1,069 & 1,495 & 40.9 & 32.8 & 45.6 & 12.2 & 0.31 \\
\hline & 12 & 31.6 & 31.0 & 1,246 & 1,037 & 1,420 & 39.7 & 33.2 & 45.1 & 12.9 & 0.26 \\
\hline \multirow[t]{3}{*}{$\mathrm{H} 2$} & 4 & 26.7 & 27.1 & 1,141 & 854 & 1,189 & 42.6 & 32.0 & 44.6 & 12.7 & 0.55 \\
\hline & 8 & 29.4 & 29.3 & 1,206 & 932 & 1,339 & 41.2 & 31.8 & 45.5 & 11.6 & 0.40 \\
\hline & 12 & 29.2 & 28.8 & 1,145 & 969 & 1,332 & 39.6 & 33.6 & 45.6 & 11.3 & 0.35 \\
\hline \multirow[t]{4}{*}{ H3 } & 4 & 25.8 & 24.9 & 994 & 822 & 1,165 & 38.8 & 32.2 & 45.3 & 11.4 & 0.61 \\
\hline & 8 & 27.6 & 27.3 & 1,093 & 902 & 1,263 & 39.5 & 32.8 & 45.6 & 11.2 & 0.72 \\
\hline & 12 & 30.8 & 30.1 & 1,197 & 987 & 1,432 & 38.9 & 32.2 & 46.5 & 12.3 & 0.37 \\
\hline & 16 & 29.3 & 28.7 & 1,153 & 945 & 1,334 & 39.5 & 32.3 & 45.4 & 10.6 & 0.46 \\
\hline SEM $^{2}$ & & 1.70 & 1.60 & 71.0 & 46.2 & 74.0 & 0.97 & 0.69 & 0.54 & 0.56 & 0.110 \\
\hline$P$-value & $\operatorname{Diet}^{3}$ & 0.02 & 0.008 & 0.03 & $<0.001$ & 0.004 & NS & NS & NS & 0.02 & 0.1 \\
\hline \multirow[t]{6}{*}{$P$-value } & Contrasts $^{4}$ & & & & & & & & & & \\
\hline & LH & 0.03 & 0.009 & 0.006 & 0.006 & 0.05 & 0.06 & NS & NS & 0.01 & 0.01 \\
\hline & $\mathrm{QH}$ & NS & NS & NS & NS & NS & 0.07 & NS & NS & NS & NS \\
\hline & $\mathrm{LC}$ & 0.02 & 0.03 & NS & 0.002 & 0.007 & 0.07 & NS & NS & NS & 0.05 \\
\hline & $\mathrm{QC}$ & NS & NS & NS & NS & NS & NS & NS & $\mathrm{NS}$ & 0.09 & NS \\
\hline & $\mathrm{H} \times \mathrm{C}$ & NS & NS & NS & NS & NS & NS & NS & NS & NS & NS \\
\hline \multirow[t]{2}{*}{$P$-value } & WIM $^{5}$ & $<0.001$ & $<0.001$ & $<0.001$ & $<0.001$ & $<0.001$ & $<0.001$ & $<0.001$ & $<0.001$ & $<0.001$ & NS \\
\hline & Diet $\times$ WIM & $<0.001$ & $<0.001$ & $<0.001$ & $<0.001$ & $<0.001$ & 0.03 & NS & NS & NS & NS \\
\hline
\end{tabular}

${ }^{1}$ Where $4 \mathrm{~kg}$ is protein concentrate only; 8,12 , and $16 \mathrm{~kg}=4 \mathrm{~kg}$ of protein concentrate plus grain concentrate to total level.

${ }^{2}$ For the diet with 1 missing value (H2, $12 \mathrm{~kg}$ of concentrate), SEM was multiplied by 1.10 .

${ }^{3}$ All 11 diets.

${ }^{4}$ Contrasts including only the 9 diets with 4,8 , or $12 \mathrm{~kg}$ of concentrates. $\mathrm{LH}$ and $\mathrm{QH}=$ linear and quadratic effects of harvesting time, $\mathrm{LC}$ and $\mathrm{QC}=$ linear and quadratic effects of concentrate level, $\mathrm{H} \times \mathrm{C}=$ harvesting time $\times$ concentrate level interaction.

${ }^{5} \mathrm{WIM}=$ week in milk.

was higher than obtained by Ferris et al. (1999, 2001) with TMR and a maximum concentrate proportion of $80 \%$. However, most studies have been performed later in lactation, when the physiological status (hormones) of the cow supports milk yield to a lower degree (Yan et al., 2006), and therefore also feed intake, compared with the present study. Kuoppala et al. (2008), however, obtained slightly higher feed intakes compared with this study, also with early harvested, well-preserved grass, from the primary growth in northern latitudes. At the same morphological stage, the digestibility of the whole grass crop is higher at northern than at southern latitudes due to lower temperatures that delay stem lignifications. The daily decline in digestibility, however, is higher at northern latitudes due to a more rapid stem development and a smaller proportion of leaf DM (Deinum et al., 1981). Silage DM intake indexes (SDMI index; Huhtanen et al., 2007) were calculated to be 120, 109, and 104 for $\mathrm{H} 1, \mathrm{H} 2$, and $\mathrm{H} 3$, respectively, where a well-fermented standard silage with $25 \%$ DM, $68 \%$ DOMD, and $80 \%$ total fermentation acids in DM has an index of 100.

Substitution rates (SR; reduction in silage DM intake/kg DM increased concentrate intake) calculated for WIM 5 to 16 , when the increase in concentrate al- lowance following calving was completed for all diets, were close to zero for $\mathrm{H} 1$ and $\mathrm{H} 2$, for concentrate allowances up to $\mathrm{C} 8$. This might be related to the protein concentrate used for the first $4 \mathrm{~kg}$, because clear evidence exists that protein supplements reduce SR (Thomas, 1987; Huhtanen et al., 2008c). The low EB of cows offered diets $\mathrm{H} 1 \mathrm{C} 0, \mathrm{H} 2 \mathrm{C} 4$, and $\mathrm{H} 3 \mathrm{C} 4$ might have contributed to this low SR (Faverdin et al., 1991). Huhtanen et al. (2008c) found a quadratic relationship between CDMI and SDMI, which suggests that SR may be very low at low CDMI. For H3, SR increased with increasing concentrate allowance, and was $0.31,0.49$, and 0.95 in the intervals $\mathrm{C} 4$ to $\mathrm{C} 8, \mathrm{C} 8$ to $\mathrm{C} 12$, and $\mathrm{C} 12$ to $\mathrm{C} 16$, respectively, which is in agreement with results of Faverdin et al. (1991) and Huhtanen et al. (2008c). In the interval $\mathrm{C} 8$ to $\mathrm{C} 12$, SR decreased with increasing crop maturity stage, and was $1.11,0.55$, and 0.49 for $\mathrm{H} 1, \mathrm{H} 2$, and $\mathrm{H} 3$, respectively. For SR calculated for lactation stages WIM 6 to 10 and 11 to 16, respectively, no time effect was detected, which is in line with Huhtanen et al. (2008c). The TDMI observed for the 11 diets on average for WIM 1 to 16 were well predicted by the relative total diet intake index (Huhtanen et al., 2008c): TDMI $(\mathrm{kg})=9.58+0.105 \times$ TDMI index; $\mathrm{R}^{2}$ $=0.88$, root mean square error $=0.85, P<0.001$. 
Table 7. Effect of harvesting time for grass silage (H1, H2, H3) and level of concentrate supplement on BW, BW gain (BWG), energy balance (EB), milk acetone concentrations, $\mathrm{N}$ use efficiency, and feed conversion rate [mean values for lactation week (WIM) 1-12 for acetone, otherwise WIM 1-16, except for BW]

\begin{tabular}{|c|c|c|c|c|c|c|c|c|}
\hline \multirow{2}{*}{$\begin{array}{l}\text { Silage } \\
\text { harvest time }\end{array}$} & \multirow{2}{*}{$\begin{array}{l}\text { Concentrate } \\
\text { level, } \mathrm{kg}^{1}\end{array}$} & \multicolumn{2}{|c|}{$\mathrm{BW}, \mathrm{kg}$} & \multirow{2}{*}{$\begin{array}{l}\text { BWG, } \\
\text { g/d }\end{array}$} & \multirow{2}{*}{$\begin{array}{l}\mathrm{EB}, \mathrm{MJ} \\
\text { of } \mathrm{NE}_{\mathrm{L}} / \mathrm{d}\end{array}$} & \multirow{2}{*}{$\begin{array}{l}\text { Milk acetone, } \\
\operatorname{m} M\end{array}$} & \multirow{2}{*}{$\begin{array}{c}\text { Milk N/N } \\
\text { intake }^{2}\end{array}$} & \multirow[b]{2}{*}{$\mathrm{ECM} / \mathrm{DMI}^{3}$} \\
\hline & & WIM 1 & WIM 16 & & & & & \\
\hline \multirow[t]{4}{*}{ H1 } & 0 & 579 & 566 & -134 & 1.4 & 0.21 & 0.275 & 1.42 \\
\hline & 4 & 566 & 581 & 152 & 12.0 & 0.11 & 0.256 & 1.42 \\
\hline & 8 & 610 & 619 & 88 & 19.3 & 0.11 & 0.258 & 1.40 \\
\hline & 12 & 565 & 591 & 264 & 26.0 & 0.09 & 0.249 & 1.32 \\
\hline \multirow[t]{3}{*}{$\mathrm{H} 2$} & 4 & 608 & 588 & -204 & -5.8 & 0.18 & 0.295 & 1.52 \\
\hline & 8 & 602 & 619 & 166 & 6.3 & 0.11 & 0.275 & 1.41 \\
\hline & 12 & 620 & 652 & 330 & 19.5 & 0.09 & 0.260 & 1.27 \\
\hline \multirow[t]{4}{*}{ H3 } & 4 & 592 & 573 & -185 & -9.4 & 0.20 & 0.333 & 1.39 \\
\hline & 8 & 630 & 631 & 16 & -2.6 & 0.07 & 0.311 & 1.35 \\
\hline & 12 & 590 & 606 & 153 & 1.3 & 0.08 & 0.309 & 1.40 \\
\hline & 16 & 567 & 572 & 58 & 8.6 & 0.07 & 0.295 & 1.37 \\
\hline $\mathrm{SEM}^{3}$ & & 22.5 & 20.7 & 103.0 & 5.18 & 0.042 & 0.0143 & 0.077 \\
\hline$P$-value & $\operatorname{Diet}^{4}$ & NS & NS & 0.008 & $<0.001$ & NS & 0.001 & NS \\
\hline \multirow[t]{6}{*}{$P$-value } & Contrasts $^{5}$ & & & & & & & \\
\hline & LH & NS & NS & 0.04 & $<0.001$ & NS & $<0.001$ & NS \\
\hline & $\mathrm{QH}$ & NS & NS & NS & NS & NS & NS & NS \\
\hline & $\mathrm{LC}$ & NS & 0.04 & $<0.001$ & $<0.001$ & 0.03 & 0.08 & 0.07 \\
\hline & $\mathrm{QC}$ & NS & 0.1 & NS & NS & NS & NS & NS \\
\hline & $\mathrm{H} \times \mathrm{C}$ & NS & NS & NS & NS & NS & NS & NS \\
\hline \multirow{2}{*}{$P$-value } & $\mathrm{WIM}^{7}$ & & & & $<0.001$ & 0.03 & $<0.001$ & $<0.001$ \\
\hline & Diet $\times$ WIM & & & & NS & NS & 0.05 & NS \\
\hline
\end{tabular}

${ }^{1}$ Where $4 \mathrm{~kg}$ is protein concentrate only; 8,12 , and $16 \mathrm{~kg}=4 \mathrm{~kg}$ of protein concentrate plus grain concentrate to total level.

${ }^{2} \mathrm{~N}$ use efficiency $=\mathrm{N}$ in milk/total $\mathrm{N}$ intake.

${ }^{3}$ Feed conversion rate $=\mathrm{ECM}$ yield, $\mathrm{kg} / \mathrm{DM}$ intake, $\mathrm{kg}$.

${ }^{4}$ For the diet with 1 missing value (H2, $12 \mathrm{~kg}$ of concentrate), SEM was multiplied by 1.10 .

${ }^{5}$ All 11 diets.

${ }^{6}$ Contrasts including only the 9 diets with 4,8 , or $12 \mathrm{~kg}$ of concentrates. $\mathrm{LH}$ and $\mathrm{QH}=$ linear and quadratic effects of harvesting time, $\mathrm{LC}$ and $\mathrm{QC}=$ linear and quadratic effects of concentrate level, $\mathrm{H} \times \mathrm{C}=$ harvesting time $\times$ concentrate level interaction.

${ }^{7} \mathrm{WIM}=$ week in milk.

Cows offered H3C16 increased TDMI and milk yield much more slowly in early lactation than cows offered other diets. The 0.5 -kg daily concentrate increase contained slightly more starch and WSC $(422 \mathrm{~g} / \mathrm{kg}$ of DM) than the daily increase given to other cows $(308,397$, and $415 \mathrm{~g} / \mathrm{kg}$ of DM for $\mathrm{C} 4, \mathrm{C} 8$, and $\mathrm{C} 12$, respectively). For cows offered $\mathrm{H} 3 \mathrm{C} 16$, the increase in concentrate intake was followed by a concomitant decrease in SDMI from WIM 2 to 6 , giving an increased ratio of rapidly (starch + WSC) to slowly (NDF) digestible carbohydrates, which reached a maximum of 0.768 in WIM 7 to 8 . During the same weeks, eating time decreased for these cows, and thereby the buffering effect from saliva on the rumen environment. Although none of the cows offered H3C16 went "off feed" or were sick at any time, and milk fat depression did not occur, NDF digestion might have been reduced when concentrate level increased (Rinne et al., 1999a; Ferris et al. 2001) to such a level that diet OM digestibility was also reduced (Nousiainen et al., 2009).

For all diets, total NDF intake was above the level $(12.5 \mathrm{~g} / \mathrm{kg}$ of BW) recommended by Mertens and Fahey (1994) that is assumed to support maximum milk yield on maize-based diets. Nordic grass crops have higher NDF concentration than North American maize-based diets (Huhtanen and Hristov, 2009). However, the high NDF intake by cows offered $\mathrm{H} 3 \mathrm{C} 4$ suggests that diet intake was strongly constrained by rumen fill. Those animals spent more time eating silage than other cows in an effort to meet their nutrient requirements.

\section{Eating Time}

The observed eating times for silage were much shorter than those recorded using the IGER behavior recorder (Rutter et al., 1997) with silage supplemented with $6 \mathrm{~kg}$ of concentrates and grass silages with similar DOMD values to $\mathrm{H} 1$ and $\mathrm{H} 2$ in a previous study (Garmo et al., 2008). In that study, silages had lower DM concentrations but were restrictedly fermented, and SDMI was high. In the meta-analysis of studies with chewing time performed by Nørgaard et al. (2010), only one study had similar eating time to the $271 \mathrm{~min} / \mathrm{d}$ for $\mathrm{H} 3 \mathrm{C} 4$ in the present study: $282 \mathrm{~min} / \mathrm{d}$ for cows consuming 14 $\mathrm{kg}$ DM of grass silage supplemented with $2.6 \mathrm{~kg}$ DM of concentrates. Eating time for silage calculated accord- 
ing to Nørgaard et al. (2010) was found to be 100, 90, and $60 \%$ higher than the observed eating times for $\mathrm{H} 1$, $\mathrm{H} 2$, and $\mathrm{H} 3$, respectively. Whereas the study of Garmo et al. (2008) and the majority of studies underlying the investigation of Nørgaard et al. (2010) were undertaken in tie-up barns, the present study was performed with cows in loose housing. However, because the numbers of feed bins and cows were always the same, cows had no reason to be stressed and thus eat extremely rapidly. The present study was performed somewhat earlier in lactation than the study by Garmo et al. (2008), where cows were in WIM 4 to 22 . Eating time for silage increased slightly with time in the present study, but the full reason for the short silage eating times was not found.

\section{Milk Production, EB, and Nutrient Utilization}

The mean daily milk yield of cows fed silage only (H1C0) was slightly greater than that obtained by Steinshamn and Thuen (2008) in organic production. Cows fed silage only were in negative EB until WIM 5 and had MP supply below requirements until WIM 10. Although moderate negative EB in early lactation may be easily compensated for by mobilization of body fat stores, a deficient supply of MP may be compensated only to a smaller extent by mobilization (NRC, 2001), with a resultant reduction in milk yield. Due to increased energy intake, any supplementation of $\mathrm{H} 1$ with concentrates is expected to reduce the risk of ketosis and, at the same time, the first kilograms of supplementary concentrate would give a high milk yield response. The response to the first $4 \mathrm{~kg}$ of protein supplement to $\mathrm{H} 1$ was $1.6 \mathrm{~kg}$ of ECM/ $\mathrm{kg}$ of CDMI, or $0.12 \mathrm{~kg}$ of ECM/MJ of ME, and the response to the next $4 \mathrm{~kg}$ (grain concentrate) was $1.1 \mathrm{~kg}$ of ECM $/ \mathrm{kg}$ of additional CDMI, or $0.10 \mathrm{~kg}$ of ECM/MJ of ME.

Cows offered $\mathrm{H} 1 \mathrm{C} 4$ and $\mathrm{H} 1 \mathrm{C} 8$ diets were in positive EB from WIM 3 and 2, respectively, and met their MP requirements from WIM 4 and 3, respectively. None of the other diets equaled the milk yield of diet $\mathrm{H} 1 \mathrm{C} 8$, which is in line with the findings of Kristensen and Skovborg (1990) and Aston et al. (1994). Diet H1C8 contained $30 \%$ concentrate and supported a daily yield of $1.34 \mathrm{~kg}$ of milk fat and $1.07 \mathrm{~kg}$ of milk protein, slightly below that reported by Ferris et al. (2001). Cows offered $\mathrm{H} 2 \mathrm{C} 4$ and $\mathrm{H} 3 \mathrm{C} 4$ were in positive $\mathrm{EB}$ from WIM 11 and 10, respectively, and met their MP requirements from WIM 11 and 8, respectively. Their milk yield was most probably limited by energy intake because they were provided with more $\mathrm{MP}\left(/ \mathrm{MJ}\right.$ of $\mathrm{NE}_{\mathrm{L}}$ ) than cows offered H1C4, but TDMI and milk yield were considerably lower.
The negative $\mathrm{EB}$ of cows offered $\mathrm{H} 1 \mathrm{C} 0, \mathrm{H} 2 \mathrm{C} 4$, and $\mathrm{H} 3 \mathrm{C} 4$ corresponded well with the BW loss observed for these cows during the first weeks of lactation. The relatively high MP supply provided to cows offered C4 diets from the protein concentrate was probably of great importance for their milk yield. The system used for concentrate allocation (protein concentrate as the first $4 \mathrm{~kg}$ and later grain concentrate) was chosen because it is known that forage plus grain provides too little MP to support a high milk yield, and the AA composition in such a diet is not optimal for milk protein synthesis, with histidine as the first-limiting amino acid (Vanhatalo et al., 1999). On the other hand, the system for concentrate allocation seems to have been unfavorable to cows offered the highest concentrate levels. The highest concentrate allowance within each silage type appears to have reduced rumen fiber digestion so that milk yield declined ( $\mathrm{H} 1$ and $\mathrm{H} 3$ ) or remained similar to the yield obtained with $4 \mathrm{~kg}$ less concentrates (H2). Both energy ( $\mathrm{ME}$ and $\mathrm{NE}_{\mathrm{L}}$ ) concentrations and $\mathrm{MP}$ concentrations were overestimated for the $\mathrm{C} 12$ and $\mathrm{C} 16$ diets, because diet NDF digestion decreases linearly with increased concentrate intake (Nousiainen et al., 2009). At least for $\mathrm{H} 3$ diets, concentrate with higher protein content for cows offered $\mathrm{C} 12$ and $\mathrm{C} 16$ would probably have improved fiber digestion (Nousiainen et al., 2009) and reduced silage SR, giving improved supply of both energy and MP. Maximum diet digestibility and maximum milk yield were found at diet CP concentrations of $220 \mathrm{~g} / \mathrm{kg}$ of DM (NRC, 2001; Nousiainen et al., 2009), whereas the present diets contained from 135 to $175 \mathrm{~g}$ of $\mathrm{CP} / \mathrm{kg}$ of DM. Compared with concentrates offered in 2 daily meals, as in the study by Kristensen and Skovborg (1990), the feeding of small amounts of concentrate in frequent meals, as in the present study, did not seem to improve the milk yield response to high CDMI.

Although milk fat concentration tended to decrease with increased concentrate intake, no milk fat depression was observed. A high acetate plus butyrate to propionate ratio in the rumen of cows fed restrictedly fermented grass silages provides easily available precursors for milk fat synthesis (Huhtanen et al., 2003). Therefore, milk fat depression is seldom found in cows fed grass silage. Milk fat concentration decreased from 45.7 to $35.7 \mathrm{~g} / \mathrm{kg}$ in the study of Ferris et al. (2001) when the concentrate proportion in the TMR was increased from 32 to 80\%. De Brabander et al. (1999) suggested that feeding grass silage might result in a lower risk of ruminal disorders than feeding maize silage.

Milk urea $\mathrm{N}$ was slightly below that often found for high-yielding dairy cows (Rinne et al., 1999b; Huhtanen et al. 2008b). The increase in milk FFA concentrations 
with increasing crop maturity stage and with decreasing concentrate level suggest that FFA increases with decreasing energy intake or decreasing EB in dairy cows in early lactation.

The efficiency of transferring dietary $\mathrm{N}$ to milk $\mathrm{N}$ found for cows offered silage as the sole feed ( $\mathrm{H} 1 \mathrm{C} 0)$ was below that found by Steinshamn and Thuen (2008) for grass silages containing $34 \%$ red or white clover. The total average $\mathrm{N}$ use efficiency was 0.283 , in line with Huhtanen et al. (2008a), who found, in a metaanalysis, that $\mathrm{N}$ use efficiency averaged 0.277 and was poorly related to milk yield, and that dietary $\mathrm{CP}$ concentration was the best predictor of $\mathrm{N}$ use efficiency. In the present study, $\mathrm{N}$ use efficiency was highest with $\mathrm{H} 3$ diets, which contained the lowest $\mathrm{CP}$ concentrations and gave milk with the lowest MUN concentrations. The high values found for $\mathrm{N}$ use efficiency and feed conversion rate in the first weeks of lactation were most likely due to mobilization of body reserves.

\section{CONCLUSIONS}

The present study documents that a reasonably high milk yield can be obtained solely from grass silage if herbage is harvested at a very early stage of maturity and is well preserved. Highly digestible grass silage resulted in the highest milk yield. The lower digestibility of silage could not be compensated for by increasing the concentrate supplementation. The energy-corrected milk yield response to concentrate intake with $\mathrm{H} 1, \mathrm{H} 2$, and H3 suggested that 8.0, 8.4, and $11.5 \mathrm{~kg}$ of concentrate supplementation of the 3 respective silages was optimal for high milk yield. Higher concentrate input reduced milk yield and thereby decreased efficiency of nutrient use.

\section{ACKNOWLEDGMENTS}

This work was financed by the Foundation for Research Levy on Agricultural Products, the Agricultural Agreement Research Fund, and the companies TINE BA (Ås, Norway), Felleskjøpet Fôrutvikling BA (Trondheim, Norway), Animalia (Oslo, Norway), Addcon Nordic AS (Porsgrunn, Norway), and Yara Norge AS (Oslo, Norway) through signed contract with the Research Council of Norway. The authors thank the following persons, all working at the Norwegian University of Life Sciences (Ås, Norway): Egil Prestløkken and Torstein H. Garmo for valuable discussions in planning the experiment, Are H. Aastveit for his recommendations to the experimental design, Morten Svendsen for advice with statistical analyses, Hallvard Gjøstein for his great contribution with the milk and feed samples, and the staff at the Animal Production Experimental Centre for feeding and taking care of the cows.

\section{REFERENCES}

Aston, K., C. Thomas, S. R. Daley, and J. D. Sutton. 1994. Milk production from grass-silage diets - Effects of the composition of supplementary concentrates. Anim. Prod. 59:335-344.

Borreani, G., and E. Tabacco. 2008. New oxygen barrier stretch film enhances quality of alfalfa wrapped silage. Agron. J. 100:942-948.

Charmley, E. 2001. Towards improved silage quality-A review. Can. J. Anim. Sci. 81:157-168.

Cushnahan, A., and F. J. Gordon. 1995. The effects of grass preservation on intake, apparent digestibility and rumen degradation characteristics. Anim. Sci. 60:429-438.

Cushnahan, A., and C. S. Mayne. 1995. Effects of ensilage of grass on performance and nutrient utilization by dairy cattle. 1. Food intake and milk production. Anim. Sci. 60:337-345.

De Brabander, D. L., J. L. De Boever, J. M. Vanacker, Ch. V. Boucque, and S. M. Botterman. 1999. Evaluation of physical structure in dairy cattle nutrition. Pages 111-145 in Recent Advances in Animal Nutrition. P. C. Garnsworthy and P. C. Wiseman, ed. Nottingham University Press, Nottingham, UK.

Deinum, B., J. Debeyer, P. H. Nordfeldt, A. Kornher, O. Ostgard, and G. Vanbogaert. 1981. Quality of herbage at different latitudes. Neth. J. Agric. Sci. 29:141-150.

Dewhurst, R. J., W. J. Fisher, J. K. S. Tweed, and R. J. Wilkins. 2003 Comparison of grass and legume silages for milk production. 1. Production responses with different levels of concentrate. J. Dairy Sci. 86:2598-2611.

Ekern, A. 1991. Nytt system for energivurdering av fôr til drøvtyggere. Norsk Landbruksforskning 5:273-277.

Faverdin, P., J. P. Dulphy, J. B. Coulon, R. Verite, J. P. Garel, J. Rouel, and B. Marquis. 1991. Substitution of roughage by concentrates for dairy-cows. Livest. Prod. Sci. 27:137-156.

Ferris, C. P., F. J. Gordon, D. C. Patterson, D. J. Kilpatrick, C. S. Mayne, and M. A. McCoy. 2001. The response of dairy cows of high genetic merit to increasing proportion of concentrate in the diet with a high and medium feed value silage. J. Agric. Sci. $136: 319-329$

Ferris, C. P., F. J. Gordon, D. C. Patterson, C. S. Mayne, and D. J. Kilpatrick. 1999. The influence of dairy cow genetic merit on the direct and residual response to level of concentrate supplementation. J. Agric. Sci. 132:467-481.

Garmo, T. H., A. T. Randby, M. Eknæs, E. Prestløkken, and P. Nørgaard. 2008. Effect of grass silage chop length on chewing activity and digestibility. Grassl. Sci. Eur. 13:810-812.

Huhtanen, P., and A. N. Hristov. 2009. A meta-analysis of the effects of dietary protein concentration and degradability on milk protein yield and milk $\mathrm{N}$ efficiency in dairy cows. J. Dairy Sci. 92:3222-3232.

Huhtanen, P., J. I. Nousiainen, H. Khalili, S. Jaakkola, and T. Heikkila. 2003. Relationships between silage fermentation characteristics and milk production parameters: Analyses of literature data. Livest. Prod. Sci. 81:57-73.

Huhtanen, P., J. I. Nousiainen, M. Rinne, K. Kytola, and H. Khalili. 2008a. Utilization and partition of dietary nitrogen in dairy cows fed grass silage-based diets. J. Dairy Sci. 91:3589-3599.

Huhtanen, P., M. Rinne, and J. Nousiainen. 2007. Evaluation of the factors affecting silage intake of dairy cows: A revision of the relative silage dry-matter intake index. Animal 1:758-770.

Huhtanen, P., M. Rinne, and J. Nousiainen. 2008b. Effects of silage soluble nitrogen components on metabolizable protein concentration: A meta-analysis of dairy cow production experiments. J. Dairy Sci. 91:1150-1158.

Huhtanen, P., M. Rinne, and J. Nousiainen. 2008c. Evaluation of concentrate factors affecting silage intake of dairy cows: A development of the relative total diet intake index. Animal 2:942-953. 
Kristensen, V. F., and E. B. Skovborg. 1990. Effect of cutting time on yield and quality of grass and on silage intake and milk production in dairy cows. Pages 1-37 in Joint Report No. 15. Landbrugsministeriet. Statens Planteavlsfors $\emptyset$ g, Statens Husdyrbrugsfors $\emptyset$, Denmark.

Kuoppala, K., M. Rinne, J. Nousiainen, and P. Huhtanen. 2008. The effect of cutting time of grass silage in primary growth and regrowth and the interactions between silage quality and concentrate level on milk production of dairy cows. Livest. Sci. 116:171-182.

Madsen, J., T. Hvelplund, M. R. Weisbjerg, J. Bertilsson, I. Olsson, R. Spoerndly, O. M. Harstad, H. Volden, M. Tuori, T. Varvikko, P. Huhtanen, and B. L. Olafsson. 1995. The AAT/PBV protein evaluation system for ruminants: A revision. Norwegian J. Agric. Sci. 9(Suppl. No. 19):1-37.

McNamee, B. F., V. B. Woods, D. J. Kilpatrick, C. S. Mayne, R. E. Agnew, and F. J. Gordon. 2005. The prediction of the intake potential of grass silage in the supplemented diets of lactating dairy cows. Livest. Prod. Sci. 92:233-240.

Mertens, D. R., and G. C. Fahey. 1994. Regulation of forage intake. Pages 450-493 in Forage Quality, Evaluation, and Utilization. Am. Soc. Agron., Crop Sci. Soc. Am., Soil Sci. Soc. Am., Madison, WI.

Moore, K. J., L. E. Moser, K. P. Vogel, S. S. Waller, B. E. Johnson, and J. F. Pedersen. 1991. Describing and quantifying growth-stages of perennial forage grasses. Agron. J. 83:1073-1077.

Nørgaard, P., E. Nadeau, and A. Randby. 2010. A new Nordic structure evaluation system for diets fed to dairy cows: A meta analysis. Pages 112-121 in Proc. Modelling nutrient digestion and utilization in farm animals. Wageningen Academic Publishers, Wageningen, the Netherlands.

Nousiainen, J., M. Rinne, and P. Huhtanen. 2009. A meta-analysis of feed digestion in dairy cows. 1 . The effects of forage and concentrate factors on total diet digestibility. J. Dairy Sci. 92:5019-5030.

NRC. 2001. Nutrient Requirements of Dairy Cattle. 7th rev. ed. National Academy Press, Washington, DC.

Peeters, A. 2008. Challenges for grasslands, grassland-based systems and their production potential in Europe. Grassl. Sci. Eur. 13:924.

Randby, A. T., P. Nørgaard, and M. R. Weisbjerg. 2010. Effect of increasing plant maturity in timothy-dominated grass silage on the performance of growing/finishing Norwegian Red bulls. Grass Forage Sci. 65:273-286.

Randby, A. T., I. Selmer-Olsen, and L. Baevre. 1999. Effect of ethanol in feed on milk flavor and chemical composition. J. Dairy Sci. $82: 420-428$
Rinne, M., S. Jaakkola, K. Kaustell, T. Heikkila, and P. Huhtanen. 1999a. Silages harvested at different stages of grass growth v. concentrate foods as energy and protein sources in milk production. Anim. Sci. 69:251-263.

Rinne, M., S. Jaakkola, T. Varvikko, and P. Huhtanen. 1999b. Effects of type and amount of rapeseed feed on milk production. Acta Agric. Scand. Anim. Sci. 49:137-148.

Rutter, S. M., R. A. Champion, and P. D. Penning. 1997. An automatic system to record foraging behaviour in freeranging ruminants. Appl. Anim. Behav. Sci. 54:185-195.

SAS Institute. 2008. SAS/STAT User's Guide. Release 9.2. SAS Institute Inc., Cary, NC.

Sjaunja, L. O., L. Baevre, L. Junkkarinen, J. Pedersen, and J. Setälä. 1991. A Nordic proposal for an energy corrected milk (ECM) formula. Pages 156-157 in Performance Recording of Animals: State of the Art, 1990: Proceedings of the 27th Biennial Session of the International Committee for Animal Recording. P. Gaillon and Y. Chabert, ed. Wageningen Academic Publishers, Wageningen, the Netherlands.

Steinshamn, H., and E. Thuen. 2008. White or red clover-grass silage in organic dairy milk production: Grassland productivity and milk production responses with different levels of concentrate. Livest. Sci. 119:202-215.

Thomas, C. 1987. Factors affecting substitution rates in dairy cows on silage based rations. Pages 205-218 in Recent Advances in Animal Nutrition. W. Haresign and D. J. A. Cole, ed. Butterworths, London, UK.

Van Es, A. J. H. 1978. Feed evaluation for ruminants. I. The systems in use from May 1977 onwards in the Netherlands. Livest. Prod. Sci. 5:331-345.

Vanhatalo, A., P. Huhtanen, V. Toivonen, and T. Varvikko. 1999. Response of dairy cows fed grass silage diets to abomasal infusions of histidine alone or in combinations with methionine and lysine. J. Dairy Sci. 82:2674-2685.

Yan, T., C. S. Mayne, T. W. J. Keady, and R. E. Agnew. 2006. Effects of dairy cow genotype with two planes of nutrition on energy partitioning between milk and body tissue. J. Dairy Sci. 89:1031-1042.

Zebeli, Q., D. Mansmann, H. Steingass, and B. N. Ametaj. 2010. Balancing diets for physically effective fibre and ruminally degradable starch: A key to lower the risk of sub-acute rumen acidosis and improve productivity of dairy cattle. Livest. Sci. 127:1-10. 